Brit. J. industr. Med., 1954, 11, 123.

\title{
A STUDY OF BOILS AT THREE COLLIERIES
}

\author{
O. P. EDMONDS, R. H. P. FERNANDEZ, and L. B. BATES
}

From the National Coal Board (East Midlands Division)

(RECEIVED FOR PUBLICATION JUNE 26, 1953)

It has been suggested that environmental conditions in coal mining such as high temperature, humidity, and slow movement of air, are associated with furunculosis. Boyd (1949) observed that certain pits were characterized by repeated outbreaks of boils. Schwartz and Warren (1941) and Schwartz and Goldsmith (1944) give furunculosis pride of place among the skin lesions of coal miners.

Apart from the general relationship between an adverse mine climate and furunculosis, little detailed information can be gathered from the literature about the natural history of boils as they affect the miner. The following investigation was, therefore, undertaken to find out more about this disorder among coal miners.

\section{Colliery Survey}

Three pits, where boils seemed prevalent, were chosen for study. They may be described thus :

\begin{tabular}{c|c|c|c}
\hline Pit & $\begin{array}{c}\text { Depth in } \\
\text { Feet }\end{array}$ & $\begin{array}{c}\text { Average No. } \\
\text { Employed }\end{array}$ & $\begin{array}{c}\text { Method of } \\
\text { Working }\end{array}$ \\
\hline A & 3300 & 1700 & Partly mechanized \\
B & 2100 & 1600 & Highly mechanized \\
C & $720-900$ & 1300 & $\begin{array}{c}\text { Coal, machine-cut } \\
\text { but hand-loaded }\end{array}$ \\
\hline
\end{tabular}

Several faces of these three pits showed considerable variation in mine climate during the period of this study; the ventilation rate ranged between 140 and 370 feet per minute, and the wet bulb temperatures ranged between 70 degrees and 80 degrees.

All three collieries have a medical centre under the charge of a state registered nurse who keeps individual medical records. These records for the two-year period 1950-1951 were examined and the sections relating to boils were analysed, particular attention being paid to the boil rate in the different occupational groups, the site of the lesion, and the recurrence rate. Boils were only recorded when they were reported voluntarily by the mineworkers themselves. As all three medical centres were popular, it is unlikely that there was any substantial difference in reporting between the three pits. Further, it is most improbable that there were any systematic differences in reporting between the various occupational groups.

\section{Boil Rate by Occupational Groups}

The mineworkers were divided in the first instance into three broad occupational groups: coal-face workers, men employed elsewhere below ground, and surface workers. The boil rate among these three groups is shown in Table 1.

TABLE 1

BOIL RATE BY OCCUPATIONAL GROUPS

\begin{tabular}{|c|c|c|c|c|c|c|c|c|c|c|c|c|}
\hline \multirow{2}{*}{ Pit } & \multicolumn{3}{|c|}{$\begin{array}{c}\text { Coal Face } \\
\text { Workers }\end{array}$} & \multicolumn{3}{|c|}{$\begin{array}{l}\text { Men Employed Elsewhere } \\
\text { below Ground }\end{array}$} & \multicolumn{3}{|c|}{ Surface Workers } & \multicolumn{3}{|c|}{ Total } \\
\hline & $\begin{array}{l}\text { Men } \\
\text { with } \\
\text { Boils }\end{array}$ & $\begin{array}{l}\text { Average } \\
\text { No. } \\
\text { Employed }\end{array}$ & $\%$ & $\begin{array}{l}\text { Men } \\
\text { with } \\
\text { Boils }\end{array}$ & $\begin{array}{c}\text { Average } \\
\text { No. } \\
\text { Employed }\end{array}$ & $\%$ & $\begin{array}{l}\text { Men } \\
\text { with } \\
\text { Boils }\end{array}$ & $\begin{array}{c}\text { Average } \\
\text { No. } \\
\text { Employed }\end{array}$ & $\%$ & $\begin{array}{l}\text { Men } \\
\text { with } \\
\text { Boils }\end{array}$ & $\begin{array}{c}\text { Average } \\
\text { No. } \\
\text { Employed }\end{array}$ & $\%$ \\
\hline $\mathbf{A}$ & 134 & 769 & $17 \cdot 4$ & 43 & 595 & $7 \cdot 2$ & 17 & 358 & $4 \cdot 7$ & 194 & 1722 & $11 \cdot 3$ \\
\hline B & 97 & 521 & 18.6 & 61 & 713 & 8.5 & 35 & 349 & $10 \cdot 0$ & 193 & 1583 & $12 \cdot 2$ \\
\hline C & 132 & 582 & 22.7 & 48 & 453 & 10.5 & 39 & 298 & $13 \cdot 1$ & 219 & 1333 & 16.5 \\
\hline Total & 363 & 1872 & $19 \cdot 4$ & 152 & 1761 & 8.6 & 91 & 1005 & $9 \cdot 0$ & 606 & 4638 & $13 \cdot 1$ \\
\hline
\end{tabular}


TABLE 2

BOIL RATE OF FACE WORKERS

\begin{tabular}{|c|c|c|c|c|c|c|c|c|c|c|c|c|c|}
\hline \multirow[b]{2}{*}{ Pit } & \multicolumn{3}{|c|}{ Colliers } & \multicolumn{3}{|c|}{ Rippers } & \multicolumn{3}{|c|}{ Packers } & \multicolumn{3}{|c|}{ Others } & \multirow{2}{*}{$\begin{array}{c}\text { Total } \\
\text { Boils at } \\
\text { Each Coal } \\
\text { Face }\end{array}$} \\
\hline & $\begin{array}{l}\text { Men } \\
\text { with } \\
\text { Boils }\end{array}$ & $\begin{array}{c}\text { Average } \\
\text { No. } \\
\text { Employed }\end{array}$ & $\%$ & $\begin{array}{l}\text { Men } \\
\text { with } \\
\text { Boils }\end{array}$ & $\begin{array}{c}\text { Average } \\
\text { No. } \\
\text { Employed }\end{array}$ & $\%$ & $\begin{array}{l}\text { Men } \\
\text { with } \\
\text { Boils }\end{array}$ & $\begin{array}{c}\text { Average } \\
\text { No. } \\
\text { Employed }\end{array}$ & $\%$ & $\begin{array}{l}\text { Men } \\
\text { with } \\
\text { Boils }\end{array}$ & $\begin{array}{c}\text { Average } \\
\text { No. } \\
\text { Employed }\end{array}$ & $\%$ & \\
\hline A & 106 & 458 & $23 \cdot 1$ & 11 & 101 & 10.9 & 9 & 91 & 9.9 & 8 & 119 & 6.7 & 134 \\
\hline B & 43 & 157 & $27 \cdot 4$ & 28 & 97 & 28.9 & 18 & 100 & $18 \cdot 0$ & 8 & 167 & $4 \cdot 8$ & 97 \\
\hline $\mathrm{C}$ & 61 & 211 & 28.9 & 29 & 82 & $35 \cdot 3$ & 18 & 83 & $21 \cdot 7$ & 24 & 206 & $11 \cdot 6$ & 132 \\
\hline$\overline{\text { Total }}$ & 210 & 826 & 25.4 & 68 & 280 & $24 \cdot 3$ & 45 & 274 & 16.4 & 40 & 492 & $8 \cdot 1$ & 363 \\
\hline
\end{tabular}

As the figures relate only to the first occasion when a man reported a boil, the rate of $13 \cdot 1 \%$ implies that one man in eight had a boil within the two-year period under review. The boil rate is lowest at Colliery $\mathrm{A}$ and highest at Colliery $\mathrm{C}$ for all categories of workers. There was no marked difference in the boil rate between men employed on the surface and underground away from the face, but the rate among face workers was significantly higher than that among the two former groups.

In Table 2 face workers are sub-divided into colliers, rippers, and others. Colliers actually load the coal on to the conveyor belt either by hand or mechanically. Rippers drive the main roadway as the face advances, and are responsible for its preservation. Packers fill in the waste after the coal has been removed. Others on the coalface comprise a miscellaneous group of shotfirers, conveyor erectors, borers, and cutters.

It will be seen that colliers and rippers were more commonly affected by boils than packers and "others". The rippers and the packers showed a wide range in their boil rates as between the three pits. "Other" face workers have a boil rate similar to that of workers elsewhere underground and surface workers, so one may conclude that colliers, rippers, and packers are the only men exceptionally at risk.

\section{The Distribution of Boils}

The relative frequency with which boils were distributed on different parts of the body was then related to the three broad occupational groups : coal-face workers, workers employed elsewhere below ground, and surface workers. The results of this analysis are shown in Fig. 1. (As some men reported with more than one boil the totals in this diagram exceed those in Table 2.) There are significant differences. The following conclusions may be drawn from the data presented in this figure.

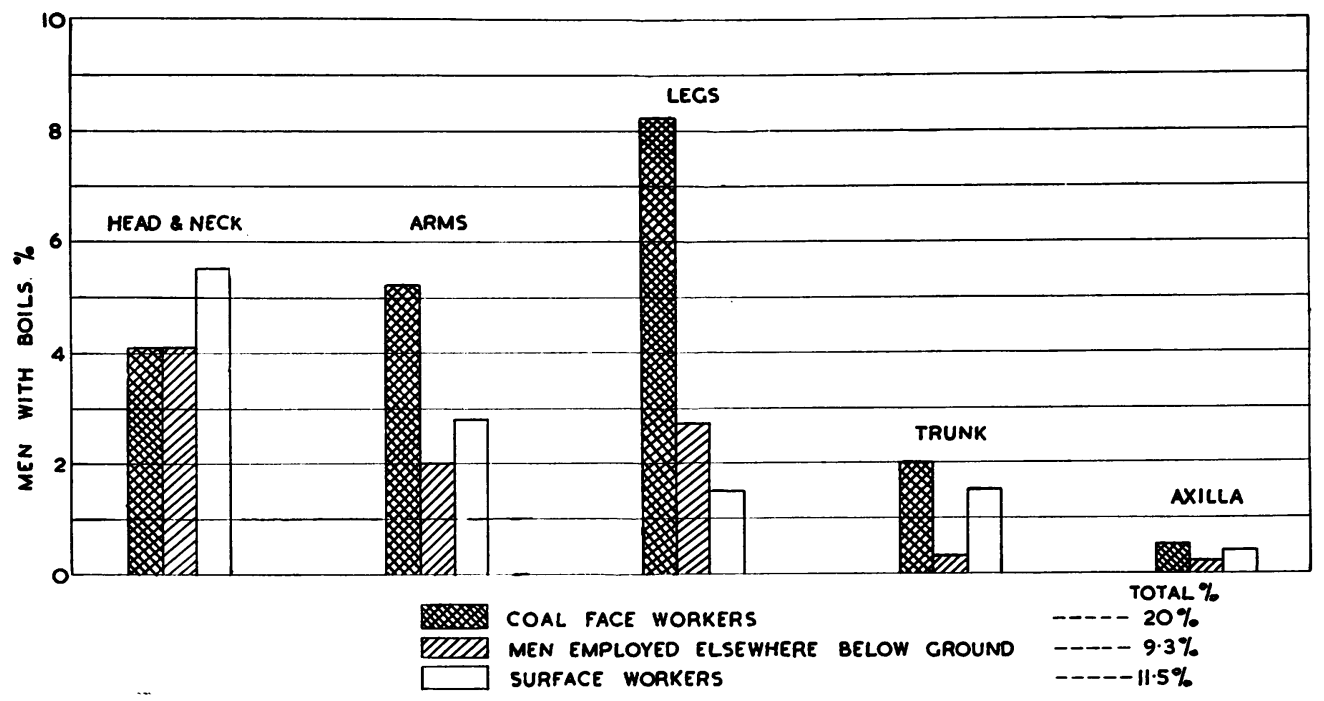

FIG. 1.-The incidence of boils by anatomical sites in the three occupational groups. 
(1) The parts of the body most commonly affected are the head, neck, and limbs. (2) The incidence of boils on the head and neck is not very different in the three broad occupational groups. (3) Among face workers the limbs are more commonly affected by boils than the head and neck. This is in striking contrast to the findings in the other two occupational groups, where there is no substantial difference between the incidence of boils on the head and neck and on the limbs.

\section{Recurrences}

The recurrence rate was calculated for the three pits. The results are shown in Table 3 .

TABLE 3

RECURRENCE RATE

\begin{tabular}{c|c|c|c}
\hline Pit & $\begin{array}{c}\text { No. of First } \\
\text { Boils }\end{array}$ & $\begin{array}{c}\text { No. of } \\
\text { Recurrences }\end{array}$ & $\begin{array}{c}\text { \% of Recurrences } \\
\text { to First Boils }\end{array}$ \\
\cline { 1 - 3 } A & 194 & 74 & $38 \cdot 1$ \\
B & 193 & 62 & $32 \cdot 1$ \\
C & 219 & 95 & $43 \cdot 4$ \\
\hline Total & 606 & 231 & $38 \cdot 0$ \\
\hline
\end{tabular}

Miners who suffer from more than one recurrence, and many did so, were still regarded for the purpose of this analysis as suffering from one recurrence only. The difference in the recurrence rate between the three pits is not significant. However, the recurrence rate is quite substantial and brings the overall attack rate up to $17.7 \%$ for the three pits in the two-year period. It may be of interest to note that at Colliery A, where figures for time lost due to occupational disease were available for the period January to June, 1952, the shifts lost on account of boils per 100,000 manshifts worked were 196, which shows that boils among mineworkers are responsible for a significant loss in coal produced.

\section{Relationship between Boil Rate and Environment}

During the two-year period when this study was carried out, the boil rate on each face of the three pits, A, B, and C, was correlated with certain environmental observations, the ventilation rate and the dry and wet bulb temperatures. It was not possible to establish any consistent correlation between the boil rate and changes in the environment. Failure to establish a correlation may have been due to the fact that the observations were not made often enough or perhaps because the aetiology of furunculosis in the mining environment is more complex than has often been assumed. The immediate cause of boils is a pyogenic skin infection, but the predisposing causes may be excessive sweating, and mechanical and chemical trauma. Increased sweating does not by itself predispose to boils ; indeed, in the spinning rooms of mills, where the atmospheric temperature is high, the workers sweat profusely, but from personal observations made in three mills they do not appear to be unduly troubled with boils. In contrast, face workers are constantly subjecting their knees and elbows to trauma. They push their shovels by pressing with knees and elbows, and the mechanical trauma is aggravated by dust particles. In certain places pit water has a high salt content, which may be a predisposing factor. Inability to obtain significant results from this part of the investigation should not discourage further efforts along these lines in future ; indeed, it might be possible to establish a boil rate index as one biological criterion of the healthiness or otherwise of the mining environment.

\section{Summary and Conclusions}

A study of boils has been carried out over a two-year period at three pits at which a high incidence of this condition was reported. The boil rate over this period was $13.1 \%$ and, if recurrences be included, the overall attack was $17 \cdot 7 \%$.

Face workers were more commonly affected than workers employed elsewhere below ground and on the surface. Colliers and rippers suffered more from boils than packers and others. Face workers had more boils on the limbs than on the head and neck. The position was reversed for miners employed below ground other than on the face and for surface workers.

Owing to the complex aetiology of furunculosis, it has not been possible to establish a clear correlation between measurements of environmental data and the boil rates.

In the three pits which were studied, boils are responsible for a significant loss of production. It is possible that a similar loss of production occurs at other pits where the underground conditions approximate to those at the pits we have surveyed.

We are grateful to Dr. John Rogan, Chief Medical Officer, and Mr. R. C. Tomlinson, Statistician, Field Investigation Group, National Coal Board, for their invaluable help in preparing this paper. Acknowledgment is also made to Dr. J. Trefor Watkins, Divisional Medical Officer, East Midlands Division, the nursing officers and officials at the three pits concerned.

\section{REFERENCES}

Boyd, J. L. (1949). Med. Press, 221, 569.

Schwartz, L., and Goldsmith, N. R. (1944). Publ. Hlth Bull. Wash., , Warren, L. H. (1941). Ibid., No. 266. 